\title{
Determination of the Endocannabinoids Anandamide and 2-Arachidonoyl Glycerol with Gas Chromatography-Mass Spectrometry: Analytical and Preanalytical Challenges and Pitfalls
}

\author{
Christian Lanz ${ }^{\mathrm{a}}$ Johan Mattsson ${ }^{\mathrm{b}}$ Felix Stickel ${ }^{\mathrm{c}}$ Jean-Francois Dufour ${ }^{\mathrm{c}, \mathrm{d}}$ \\ Rudolf Brenneisen ${ }^{a}$ \\ ${ }^{a}$ Department of Clinical Research, University of Bern, Bern, Switzerland; ${ }^{b}$ Center of Laboratory Medicine, \\ University Institute of Clinical Chemistry, University Hospital Inselspital Bern, Bern, Switzerland; \\ 'Clinic for Visceral Surgery and Medicine, University Hospital Inselspital Bern, Bern, Switzerland; \\ ${ }^{\mathrm{d}}$ Hepatology, Department of Clinical Research, University of Bern, Bern, Switzerland
}

\section{Keywords}

Endocannabinoids · Anandamide · 2-Arachidonoyl glycerol · Human plasma · Gas chromatography-mass spectrometry · Pitfalls

\begin{abstract}
Background: The endocannabinoids anandamide ( $\mathrm{N}$-arachidonoyl ethanolamide [AEA]) and 2-arachidonoyl glycerol (2-AG) are involved in the regulation of neuronal, immune, metabolic, vascular, and reproductory functions. Methods: The development and validation of an analytical method for the determination of AEA and 2-AG in human plasma based on liquid-liquid extraction and gas chromatography-mass spectrometry after silylation is described and (pre)-analytical pitfalls are identified. Results: In contrast to 2-AG, AEA was unstable in whole blood and increased by a factor of 2.3 within $3 \mathrm{~h}$ on ice. AEA was stable in plasma on ice for $4 \mathrm{~h}$
\end{abstract}

while 2-AG tended to decrease. Excellent stability at room/ ambient temperature was found for both derivatized compounds over $45 \mathrm{~h}$. Furthermore, 3 freeze-thaw cycles revealed a complex pattern: endogenous AEA was stable in plasma but slightly increased in spiked samples (+12.8\%), while endogenous 2-AG concentrations increased by $51 \%$ and declined by $24 \%$ in spiked samples. A long-term study over 4 weeks at $-80^{\circ} \mathrm{C}$ showed that low endogenous AEA and spiked 2-AG concentrations were stable. However, spiked AEA tended to increase (+19\%) and endogenous 2 -AG significantly increased by $50 \%$ after 2 weeks. Food intake $2 \mathrm{~h}$ before blood collection showed no effect on AEA concentrations, whereas 2-AG increased significantly by a factor of 3. Conclusions: Overall, limited in vitro and/or in vivo/ex vivo chemical stability of endocannabinoids has to be taken into account.

(c) 2018 The Author(s)

Published by S. Karger AG, Basel

\begin{tabular}{ll}
\hline KARGER & $\begin{array}{l}\text { ( ) 2018 The Author(s) Karger } \\
\text { Published by S. Karger AG, Basel }\end{array}$ \\
E-Mail karger@karger.com & $\begin{array}{l}\text { This article is licensed under the Creative Commons Attribution- } \\
\text { NonCommercial-NoDerivatives 4.0 International License (CC BY- } \\
\text { NC-ND) (http://www.karger.com/Services/OpenAccessLicense). } \\
\text { www.karger.com/mca and distribution for commercial purposes as well as any dis- } \\
\text { tribution of modified material requires written permission. }\end{array}$
\end{tabular}

Prof. Rudolf Brenneisen, $\mathrm{PhD}$

Swiss Task Force for Cannabinoids in Medicine (STCM)

Frikartweg 9A

$\mathrm{CH}-3006$ Bern (Switzerland)

E-Mail sacm@bluewin.ch 


\section{Introduction}

Although the medical and recreational use of Cannabis sativa L. has a very long history, the underlying molecular mechanisms responsible for the effects of cannabinoids were only revealed in recent times [1]. First indications of the existence of a specific cannabinoid receptor involving a functional $G_{i}$ protein were obtained in 1984 with the work of Howlett [2] and Howlett and Fleming [3], who found a stereospecific inhibition of adenylate cyclase by psychoactive cannabinoids such as delta-8- and delta-9-tetrahydrocannabinol (THC) in a model neuronal system. A milestone in cannabinoid research was reached in 1988 with the characterization of a specific cannabinoid receptor in the rat brain by Devane et al. [4]. These findings were confirmed in the rat and human brain and additional tissues by other groups, and the G-protein-coupled receptor was subsequently identified, named cannabinoid receptor 1 (CB1) [5-7]. In the same time period, a second G-protein-coupled cannabinoid receptor 2 (CB2) was identified and characterized from cells of the peripheral immune system [8-10]. Although the primary location of $\mathrm{CB} 1$ is the brain and neuronal tissue and CB2 is predominantly found in peripheral immunocytes, both receptors are also expressed in other tissues, and CB2 is present aside CB1 in the mammalian brain [11-13]. The wide distribution of the cannabinoid receptors contributes to the complex pharmacology of their ligands. The discovery of cannabinoid receptors provoked the search for endogenous ligands. $\mathrm{N}$-arachidonoyl ethanolamide, named anandamide (AEA), was the first endogenous agonist described in 1992 by Devane et al. [14]. In 1995, a second endogenous cannabinoid receptor agonist was identified as 2 -arachidonoyl glycerol (2-AG) $[15,16]$. Luchicchi and Pistis [17] have described the pharmacological properties, functional features, and emerging specificities of these two major endocannabinoids (ECs). Other ECs derived from polyunsaturated fatty acids were characterized subsequently [18]. Since then, research interest in the endocannabinoid system (ECS) has grown extensively and innumerous attempts have been undertaken to elucidate the complex physiological and pathophysiological role and interrelations of this system. The more insight was gathered the more evident it became that the understanding of the complexity of this system is very limited so far. Nevertheless, it is nowadays widely recognized that the ECS plays an important role in the fine-tuning of the homeostasis of many physiological key mechanisms, such as vascular, reproductory, metabolic, and immune functions. For comprehensive reviews summarizing the complexity and physiological relevance of the ECS see Di Marzo and De Petrocellis [19] and Atakan [20]. Great interest has been directed towards the pathophysiological role of the ECS in disease development and progression. This would allow evaluation of the therapeutic potential of exogenous ligands by modulation of the ECS and their use in diseases, such as cardiovascular, neurodegenerative, metabolic, and inflammatory disorders, nausea, migraine, irritable bowel diseases, pain perception, and obesity among others [21, 22].

After the discovery of ECs highly sensitive analytical tools were needed to reliably and quantitatively determine these compounds in animal and human plasma or tissue samples. For a comprehensive review of the analytical methods for the determination of ECs see Zoerner et al. [23]. Most of these methods are based on liquid chromatography-mass spectrometry (LC/MS) combined with solid-phase extraction or liquid-liquid extraction [24-30]. Alternatively, gas chromatographymass spectrometry (GC/MS) in combination with liquid-liquid extraction or solid-phase extraction has been used for the quantitation of ECs from a variety of sample matrices including plasma. Various derivatization procedures have been described to increase the volatility and chemical stability of the ECs [31-35]. In addition, increasing evidence has been gathered over time demonstrating that the sample preparation and analysis of ECs are sensitive to a variety of artifacts. Artifacts were found to be introduced during solid-phase extraction or liquid-liquid extraction [36]. Temperature-dependent chemical instability of ECs during sample processing and storage has been reported, including rapid isomerization of $2-\mathrm{AG}$ to $1-\mathrm{AG}$ depending on the $\mathrm{pH}$ and solvents of the medium [23, 30, 37, 38]. Furthermore, AEA was found to be rapidly released from blood cells ex vivo in a temperature- and time-dependent manner, emphasizing the need of strict protocols for sample collection (e.g., venipuncture) and handling $[37,38]$. Numerous factors influence the levels of ECs and strategies should be addressed to minimize artifacts during sample collection, preparation, and analysis [23]. Other factors which have an important impact on EC concentrations in blood are race, female hormonal status during the menstrual cycle, physical exercise, and moderate alcohol intake shortly before the phlebotomy [39-42]. The impact of food intake or hedonic eating on EC blood concentrations has also been studied as
Lanz/Mattsson/Stickel/Dufour/ Brenneisen 


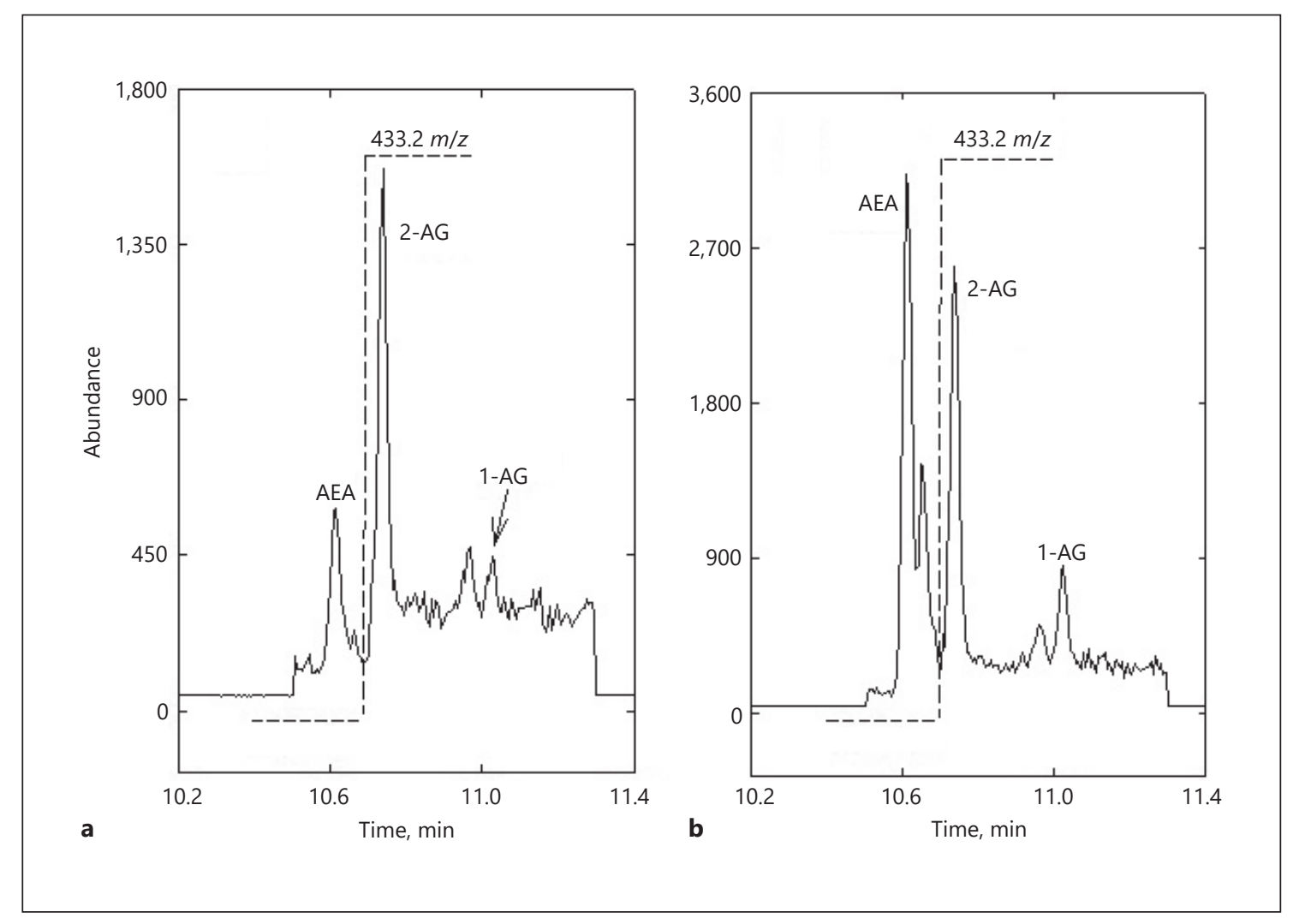

Fig. 1. Gas chromatography-mass spectrometry chromatograms obtained in selected ion monitoring mode with the plasma of a healthy volunteer with concentrations of AEA and AG being 0.69 and $1.98 \mathrm{ng} / \mathrm{mL}$, respectively (a), and pooled plasma spiked with AEA and 2-AG at $3 \mathrm{ng} / \mathrm{mL}$ (total concentrations of AEA and AG: 3.57 and $3.52 \mathrm{ng} / \mathrm{mL}$, respectively) (b). For AEA $\mathrm{m} / z 420.2$ is depicted as the quantifier ion (to the left of the dotted line), whereas $m / z 433.2$ is shown for 2-AG and 1-AG (to the right of the dotted line). For experimental conditions, see online supplementary material. AEA, anandamide; AG, arachidonoyl glycerol.

well as the interrelation with obesity and energy expenditure. However, the results remain controversial [4245].

In this study we report the development of a fully validated, highly sensitive, and relatively simple method for the simultaneous quantitation of AEA, 2-AG, and 1-AG in human plasma based on GC/MS with positive chemical ionization after liquid-liquid extraction and derivatization by silylation. Special focus is directed towards the stability of ECs and the precautions required during sample preparation in order to avoid analytical artifacts. Furthermore, preanalytical considerations including the impact of food intake and the precautions required for the collection and processing of blood samples are addressed and recommendations provided for a preanalytical and analytical standard operating procedure (SOP).

Endocannabinoids and GC/MS:

Challenges and Pitfalls

\section{Materials and Methods}

For chemicals, plasma sample collection, preparation and extraction, GC/MS procedures, method validation, and stability tests, see online supplementary material (for all online suppl. material, see www.karger.com/doi/10.1159/000489032).

\section{Results and Discussion}

\section{GC/MS Assay}

The GC/MS method was validated according to Peters et al. [46]. The assay was shown to be robust, linear, selective, reproducible, accurate, and sensitive. The chromatograms obtained in selected ion monitoring mode with the plasma of a healthy volunteer (Fig. 1a) and pooled plasma spiked with AEA and 2-AG at $3 \mathrm{ng} / \mathrm{mL}$ (Fig. $1 \mathrm{~b}$ ) are each 
Table 1. Gas chromatography-mass spectrometry intra- and interday precision and accuracy

\begin{tabular}{|c|c|c|c|c|c|c|c|}
\hline \multirow[t]{3}{*}{ Compound } & \multirow{3}{*}{$\begin{array}{l}\text { Spiked, } \\
\text { ng/mL }\end{array}$} & \multicolumn{3}{|l|}{ Intraday $(n=6)$} & \multicolumn{3}{|l|}{ Interday $(n=6)$} \\
\hline & & \multicolumn{2}{|l|}{ spiked $^{\mathrm{a}}$} & \multirow{2}{*}{$\frac{\text { total }^{\mathrm{b}}}{\text { precision }}$} & \multicolumn{2}{|l|}{ spiked $^{\mathrm{a}}$} & \multirow{2}{*}{$\frac{\text { total }^{\text {b }}}{\text { precision }}$} \\
\hline & & precision & accuracy & & precision & accuracy & \\
\hline \multirow[t]{4}{*}{ AEA } & 0.00 & na & na & $0.48 \pm 0.04(7.5)$ & na & na & $0.48 \pm 0.07(14.1)$ \\
\hline & 0.35 & $0.39 \pm 0.04(11.0)$ & +11.2 & $0.81 \pm 0.04(5.3)$ & $0.37 \pm 0.04(9.9)$ & +4.5 & $0.76 \pm 0.06(7.6)$ \\
\hline & 0.70 & $0.70 \pm 0.06(8.0)$ & -0.6 & $1.05 \pm 0.06(5.3)$ & $0.81 \pm 0.13(16.3)$ & +16.2 & $1.12 \pm 0.09(7.7)$ \\
\hline & 3.00 & $3.23 \pm 0.12(3.6)$ & +7.5 & $3.68 \pm 0.12(3.2)$ & $2.83 \pm 0.39(13.9)$ & -5.7 & $3.14 \pm 0.41(13.1)$ \\
\hline \multirow[t]{3}{*}{ AG } & 0.00 & na & na & $0.88 \pm 0.19(21.5)$ & na & na & $1.19 \pm 0.13(10.6)$ \\
\hline & 3.00 & $2.73 \pm 0.23(8.4)$ & -8.8 & $3.41 \pm 0.23(6.8)$ & $2.72 \pm 0.20(7.3)$ & -9.3 & $3.54 \pm 0.22(6.3)$ \\
\hline & 7.00 & $6.21 \pm 0.29(4.7)$ & -11.3 & $6.88 \pm 0.29(4.3)$ & $6.38 \pm 0.66(10.4)$ & -8.8 & $7.21 \pm 0.69(9.6)$ \\
\hline
\end{tabular}

Values are mean \pm SD as $\mathrm{ng} / \mathrm{mL}$ (relative SD, \%) for precision, and bias \% for accuracy (deviation from the spiked concentration).

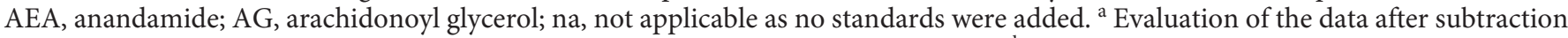
of peak area ratios obtained with blank samples (mean of 3 blank samples subtracted). ${ }^{\mathrm{b}}$ Total EC concentrations measured.

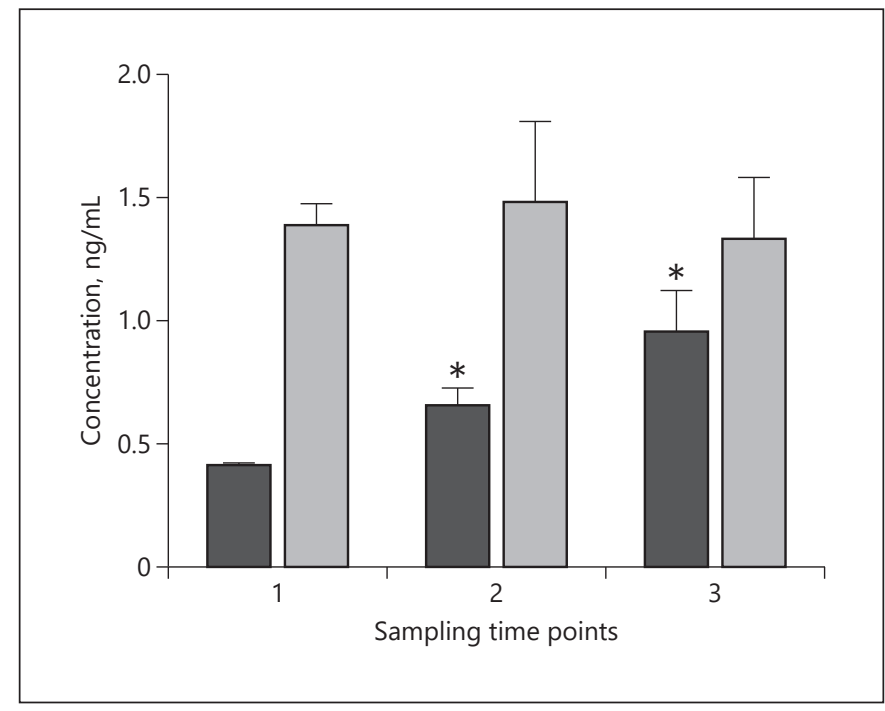

Fig. 2. Stability of AEA (black bars) and AG (grey bars) in whole blood. Depicted are mean values + SD of EC concentrations from plasma samples of 3 individuals. Blood samples were kept on ice for 15,75 , and $195 \mathrm{~min}$, referred to as sampling time points 1,2 , and 3 , respectively, before centrifugation to obtain plasma. AEA, anandamide; AG, arachidonoyl glycerol; EC, endocannabinoid. $* p<0.05$.

shown with the quantifier ion $\mathrm{m} / z 420.2$ for AEA and $\mathrm{m} / \mathrm{z}$ 433.2 for $2-A G$ and 1-AG. The concentrations of AEA and AG in the plasma of this healthy volunteer were 0.69 and $1.98 \mathrm{ng} / \mathrm{mL}$, respectively. The total EC concentrations, hereafter defined as endogenous ECs plus spiked ECs, of the sample depicted in Figure $1 \mathrm{~b}$ were $3.57 \mathrm{ng} / \mathrm{mL}$ for AEA and $3.52 \mathrm{ng} / \mathrm{mL}$ for AG. From 10.5 to $11.3 \mathrm{~min}$ the electron multiplier voltage was increased by $+1,200 \mathrm{~V}$, which is responsible for the sudden rise and decline of the baseline. Separation was achieved within $11.2 \mathrm{~min}$ with the retention times for AEA, 2-AG, and 1-AG being 10.62, 10.74, and $11.03 \mathrm{~min}$, respectively. Peak identification was accomplished by comparison of the retention times and mass spectra with those obtained with analytical standards. The calibration curve determined in pooled plasma spiked with AEA and AG was found to be linear in the range of $0.35-5.0$ and $1.0-10.0 \mathrm{ng} / \mathrm{mL}$, respectively, with coefficients of determination $\left(r^{2}\right)$ of 0.9990 and 0.9996 for AEA and AG. For the assessment of the assay performance parameters, such as limit of detection (LOD), lower limit of quantitation (LLOQ), intra- and interday precision, and accuracy, pooled plasma containing low endogenous EC concentrations (AEA: $0.48 \mathrm{ng}$ / $\mathrm{mL}$; AG: $1.19 \mathrm{ng} / \mathrm{mL}$ ) was used and spiked with defined concentrations of AEA and AG. The LLOQ of AEA and AG was 0.35 and $1.0 \mathrm{ng} / \mathrm{mL}$, respectively, whereas the LOD was 0.3 and $0.5 \mathrm{ng} / \mathrm{mL}$. The results of the intra- and interday precision and accuracy measurements of AEA, AG, and total ECs are summarized in Table 1. The applied acceptance criteria for precision of $15 \%$ relative standard deviation (RSD; $20 \%$ RSD is close to the LLOQ) and accuracy with the bias within $\pm 15 \%$ of the target value $( \pm 20 \%$ is close to the LLOQ) are widely accepted in bioanalysis [44]. With RSD $\leq 11.0 \%$ the intraday precision of the spiked concentrations was found to be good for AEA and AG at all concentration levels. The RSD of the intraday precision of the spiked EC concentrations was in general higher than that of the total EC concentrations. This can be explained by the fact that for the determination of
Lanz/Mattsson/Stickel/Dufour/ Brenneisen 
Fig. 3. Benchtop stability over $4 \mathrm{~h}$ (a) and autosampler stability over $45 \mathrm{~h}$ (b) of AEA (black bars) and AG (grey bars) in plasma spiked with AEA and 2-AG at $3 \mathrm{ng} / \mathrm{mL}$. Depicted are mean values $+\mathrm{SD}$ of total EC concentrations of 3 samples prepared in the same plasma for each time point. AEA, anandamide; AG, arachidonoyl glycerol; EC, endocannabinoid.

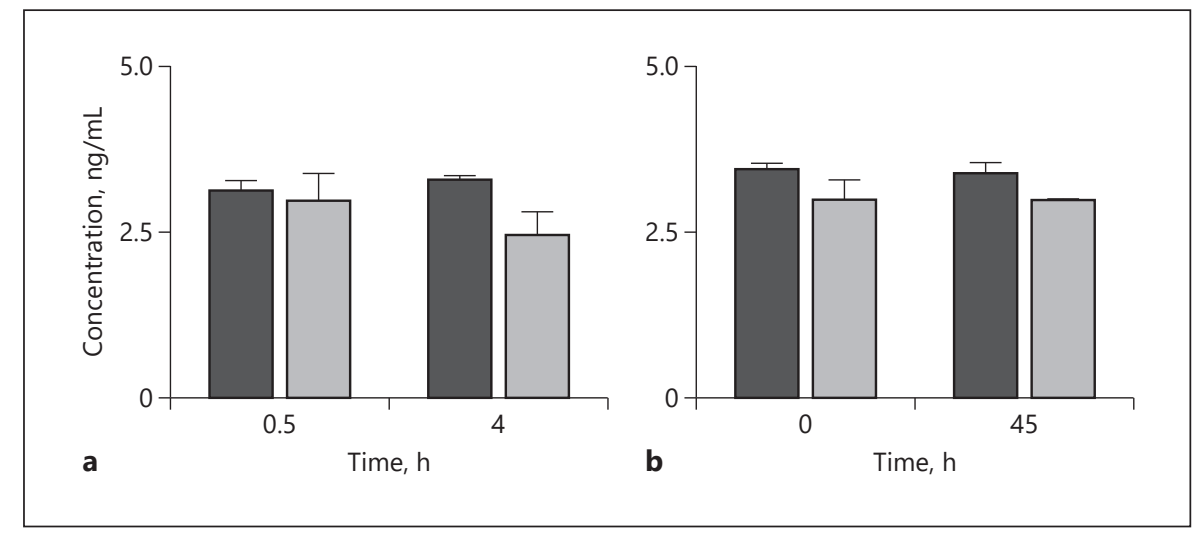

the spiked EC concentrations the endogenous EC concentrations have to be subtracted from the total EC concentrations, which introduces an additional error. The intraday accuracy of the spiked EC concentrations also fulfilled the strict acceptance criteria at all concentration levels. The inter- versus intraday precision and accuracy results were found to be less good, however, with one exception (AEA at $0.7 \mathrm{ng} / \mathrm{mL}$ ) still within the set acceptance criteria. Again, precision data obtained for the total EC concentrations were slightly better than those of the spiked concentrations. With RSD of 14.1 (AEA) and $10.6 \%$ (AG), a good interday precision was also found in the case of pooled non-spiked plasma. As no plasma without endogenous ECs was available the extraction recovery was assessed with internal standards, i.e., deuterated AEA and 2-AG in pooled blank plasma. Extraction recovery was found to be $72.2 \%$ for AEA, higher than the recovery of $A G$, which was $42.7 \%$.

\section{Stability of AEA and AG in Whole Blood}

The mean concentrations (+SD) of AEA and AG obtained from blood samples of 3 healthy individuals are shown in Figure 2. Three blood samples were collected from each of the subjects and put on ice for 15, 75, and $195 \mathrm{~min}$ (sampling time points 1, 2, and 3, respectively) before centrifugation and collection of the plasma. AEA was found to be sensitive to the time lag between the collection of whole blood and the separation of the plasma from the blood cells. The plasma concentrations of AEA were positively correlated with the time the whole blood samples were kept on ice before centrifugation $\left(r^{2}=\right.$ $0.983)$ and significantly increased with storage time $(p<$ $0.05)$. Mean values (SD; RSD) obtained at 15,75 , and 195 min were $0.41(0.008 ; 1.9 \%), 0.65(0.07 ; 10.6 \%)$, and 0.95 $(0.17 ; 17.4 \%) \mathrm{ng} / \mathrm{mL}$, respectively. Thus, AEA concentra- tions increased by a factor of 2.3 within $3 \mathrm{~h}$. RSD was very small for the first time point ( $1.9 \%$ at $15 \mathrm{~min})$, increased over time, and was highest at the last time point (17.4\% at $195 \mathrm{~min}$ ). These findings are in agreement with earlier reports $[38,47]$ where a time-dependent increase of AEA concentrations was observed in whole blood kept at $4{ }^{\circ} \mathrm{C}$ or higher temperatures. Contradicting stability data showed AEA to be stable in whole blood at room temperature for $2 \mathrm{~h}$ [48]. The remarkable increase of AEA plasma concentrations and the consecutive increase of the RSD are most probably explained by the continuous release of AEA from blood cells. This release cannot be prevented by placing blood samples on ice. These data emphasize the need for adherence to a strict SOP to ensure the immediate centrifugation of whole blood samples in order to avoid artifacts. On the other hand, AG appeared not to be affected by prolonged storage of whole blood on ice over the investigated time period. Mean concentrations (SD, RSD) obtained for the 3 time points were $1.39(0.09 ; 6.3 \%), 1.48(0.33 ; 22.4 \%)$, and $1.33(0.25$; $18.5 \%) \mathrm{ng} / \mathrm{mL}$, respectively. RSD was lowest at the first time point $(6.3 \%$ at $15 \mathrm{~min})$ and increased to $18.5-22.4 \%$ at the other time points, indicating a slight increase of variability over time. Again, these data support the findings from other studies showing that 2-AG and other monoglycerides are, in contrast to AEA and other ethanolamides, stable in whole blood for $8 \mathrm{~h}$ [38].

\section{Benchtop Stability}

Benchtop stability was assessed with pooled plasma fortified with $3 \mathrm{ng} / \mathrm{mL}$ of AEA and 2-AG. Figure 3a depicts the mean values $+\mathrm{SD}(n=3)$ of total EC concentrations obtained for AEA and AG. Three spiked plasma samples were processed according to the SOP after incubation of $30 \mathrm{~min}$ on ice and stored on ice for $4 \mathrm{~h}$ before 
Table 2. Freeze-thaw stability

\begin{tabular}{|c|c|c|c|c|}
\hline & \multicolumn{4}{|l|}{ Concentrations } \\
\hline & cycle 0 & cycle 1 & cycle 2 & cycle 3 \\
\hline AEA blank & $0.54 \pm 0.11(19.4)$ & $0.56 \pm 0.07(11.7)$ & $0.57 \pm 0.11(19.8)$ & $0.54 \pm 0.01(2.6)$ \\
\hline $\mathrm{AEA}+3 \mathrm{ng} / \mathrm{mL}$ & $3.37 \pm 0.11(3.3)$ & $3.56 \pm 0.21(5.9)$ & $3.80 \pm 0.17(4.5)$ & $3.62 \pm 0.39(10.6)$ \\
\hline AG blank & $1.21 \pm 0.11(9.3)$ & $1.57 \pm 0.18(11.5)$ & $1.83 \pm 0.24(13.0)$ & $1.68 \pm 0.07(4.2)$ \\
\hline $\mathrm{AG}+3 \mathrm{ng} / \mathrm{mL}$ & $4.03 \pm 0.34(8.5)$ & $3.94 \pm 0.37(9.3)$ & $3.60 \pm 0.23(6.5)$ & $3.06 \pm 0.20(6.5)$ \\
\hline
\end{tabular}

Values are mean $\pm \mathrm{SD}$ as $\mathrm{ng} / \mathrm{mL}$ (relative SD, \%). AEA, anandamide; AG, arachidonoyl glycerol.

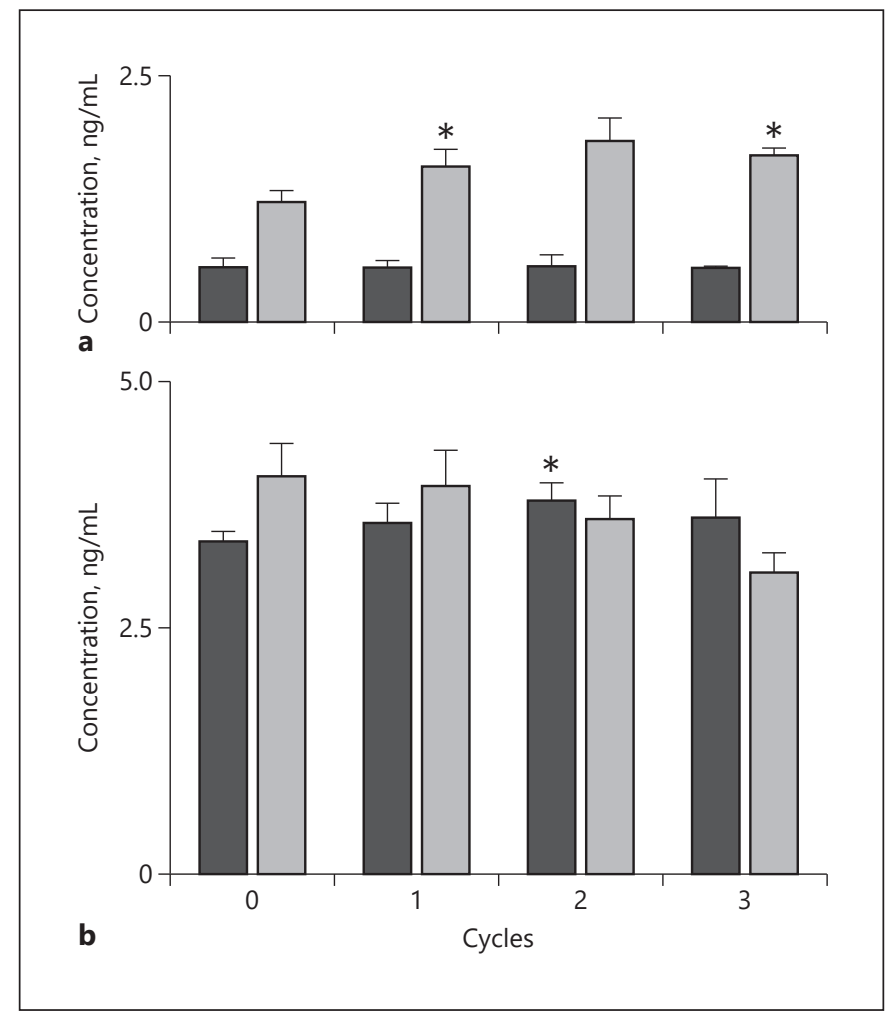

Fig. 4. Freeze-thaw stability of AEA (black bars) and AG (grey bars) over 3 cycles obtained with pooled blank plasma (a) and the same plasma spiked with AEA and 2-AG at $3 \mathrm{ng} / \mathrm{mL}$ (b). Depicted are mean values $+\mathrm{SD}$ of 3 samples. Total EC concentrations are given for the spiked samples. AEA, anandamide; AG, arachidonoyl glycerol; EC, endocannabinoid. ${ }^{*} p<0.05$ compared with the concentrations at the beginning (cycle 0$)$.

extraction and derivatization. AEA appeared to be unaffected with total EC concentrations (SD; RSD) at $30 \mathrm{~min}$ and $4 \mathrm{~h}$ being $3.14 \mathrm{ng} / \mathrm{mL}(0.14 ; 4.4 \%)$ and $3.32 \mathrm{ng} / \mathrm{mL}$ $(0.04 ; 1.3 \%)$, respectively. These results support earlier

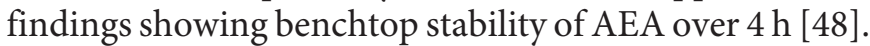

However, AG was not measured in this study. A trend to lower concentrations during the storage of plasma samples on ice for $4 \mathrm{~h}$ was observed with AG, but without reaching statistical significance. Mean values (SD; RSD) at $30 \mathrm{~min}$ and $4 \mathrm{~h}$ were $2.99 \mathrm{ng} / \mathrm{mL}(0.41 ; 13.7 \%)$ and 2.46 $\mathrm{ng} / \mathrm{mL}(0.34 ; 13.9 \%)$, respectively. The slight decrease could be attributed to the catalytic activity of plasma enzymes such as monoacylglycerol lipase.

\section{Autosampler Stability}

Autosampler stability is presented in Figure 3. Pooled plasma was spiked with AEA and 2-AG at $3 \mathrm{ng} / \mathrm{mL}$ ( $n=$ 3) and measured immediately after derivatization. The samples were kept at room temperature on the autosampler and remeasured after $45 \mathrm{~h}$ to assess autosampler stability. Mean total concentrations (SD; RSD) for AEA were $3.46 \mathrm{ng} / \mathrm{mL}(0.08 ; 2.2 \%)$ and $3.39 \mathrm{ng} / \mathrm{mL}(0.17 ; 4.9 \%)$ measured immediately and $45 \mathrm{~h}$ after derivatization, respectively. Corresponding concentrations for AG were $2.99 \mathrm{ng} / \mathrm{mL}(0.31 ; 10.2 \%)$ and $2.98 \mathrm{ng} / \mathrm{mL}(0.02 ; 0.5 \%)$, obtained for the first and second measurement, respectively. No changes within the investigated time period of $45 \mathrm{~h}$ were observed for both ECs, proving the chemical stability of the silylated derivatives after derivatization with BSTFA. This is of particular importance for the analysis of large sample sets.

\section{Freeze-Thaw Stability}

The results obtained for the freeze-thaw stability are summarized in Figure 4 and Table 2. Two concentration levels were investigated in pooled plasma for both ECs, namely the blank plasma containing low endogenous ECs (Fig. 4a) and the same plasma spiked with both ECs at 3 ng/mL (Fig. 4b). Three samples were extracted for each level before freezing (cycle 0 ) and after each of the $3 \mathrm{cy}$ cles. Depicted in Figure 4 are mean total EC concentrations + SD of AEA. For statistical analyses the concentra-
14

Med Cannabis Cannabinoids 2018;1:9-18 DOI: $10.1159 / 000489032$
Lanz/Mattsson/Stickel/Dufour/ Brenneisen 
Table 3. Long-term stability

\begin{tabular}{llll}
\hline & \multicolumn{2}{l}{ Concentrations } & \\
\cline { 2 - 3 } & 0 weeks & 2 weeks & 4 weeks \\
\hline AEA blank & $0.54 \pm 0.11(19.4)$ & $0.60 \pm 0.02(2.6)$ & $0.64 \pm 0.06(9.0)$ \\
AEA $+3 \mathrm{ng} / \mathrm{mL}$ & $3.37 \pm 0.11(3.3)$ & $3.73 \pm 0.17(4.7)$ & $4.01 \pm 0.04(1.0)$ \\
$\mathrm{AG} \mathrm{blank}$ & $1.21 \pm 0.11(9.3)$ & $1.81 \pm 0.09(4.8)$ & $1.69 \pm 0.38(22.6)$ \\
$\mathrm{AG}+3 \mathrm{ng} / \mathrm{mL}$ & $4.03 \pm 0.34(8.5)$ & $4.16 \pm 0.35(8.5)$ & $3.74 \pm 0.10(2.6)$ \\
\hline
\end{tabular}

Values are mean \pm SD as ng/mL (relative SD, \%). AEA, anandamide; AG, arachidonoyl glycerol.

tions determined after each cycle were compared with those obtained for the fresh samples (cycle 0). For details refer to Table 2. Endogenous AEA concentrations did not change over 3 freeze-thaw cycles compared to the fresh samples. However, total AEA concentrations slightly increased for the spiked samples and reached statistical significance for the second cycle $(+12.8 \% ; p=0.014)$. The same relative increase was reported for AEA by others [48]. A more complex situation was observed for AG. Here, endogenous levels (Fig. 4a) increased significantly compared to the fresh samples $(p=0.023$ and $p=0.043$ for cycles 1 and 3, respectively). The largest, but not significant, increase was observed for the second cycle (+51\%; $p=0.08)$. In contrast, total AG concentrations of spiked plasma samples (Fig. 4b) showed a tendency to decrease for the second and third cycles, but without reaching statistical significance. Lowest concentrations were found for the last cycle $(-24 \% ; p=0.25)$. This could be explained by hydrolysis of AG to arachidonic acid and glycerol. These findings are in contrast to an earlier study claiming ethanolamine and glycerol derivatives to be stable over 3 freeze-thaw cycles [38]. The results reported here indicate the susceptibility of AEA and AG to artifacts produced by repeated thawing and freezing. The differences found in the concentration-time relationship of both ECs between non-spiked and spiked plasma may be attributed to the fact that endogenous ECs are partly bound to proteins, which is not the case for the spiked ECs.

\section{Long-Term Stability}

Long-term stability was assessed for AEA and AG after 2 and 4 weeks of storage at $-80^{\circ} \mathrm{C}$ compared to fresh samples (0 weeks). Mean values + SD of 3 samples for each concentration and time point are depicted in Figure 5. For details refer to Table 3. Endogenous AEA was not affected by storage at $-80^{\circ} \mathrm{C}$ over 4 weeks (Fig. $5 \mathrm{a}$ ). On the

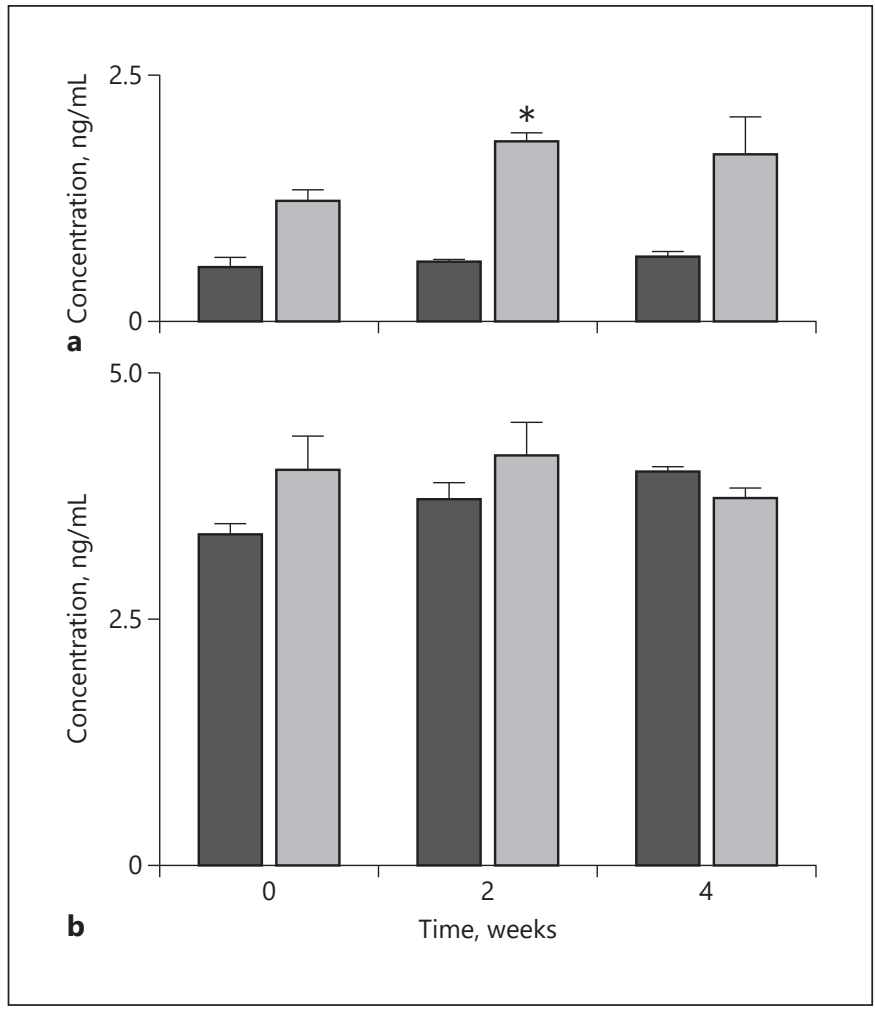

Fig. 5. Long-term stability of AEA (black bars) and AG (grey bars) before and 2 and 4 weeks after storing the samples at $-80^{\circ} \mathrm{C}$ obtained with pooled blank plasma (a) and the same plasma spiked with AEA and 2-AG at $3 \mathrm{ng} / \mathrm{mL}$ (b). Mean values + SD of 3 samples are presented for each time point. Total EC concentrations are given for the spiked samples. AEA, anandamide; AG, arachidonoyl glycerol; EC, endocannabinoid. ${ }^{*} p<0.05$ compared with the concentrations at the beginning (before freezing).

other hand, a slight but statistically not significant increase of total AEA was observed over time in spiked plasma samples $(+19 \%$ at 4 weeks; $p=0.25$; Fig. 5b). Endogenous AG levels (Fig. 5a) significantly increased by $50 \%$ 


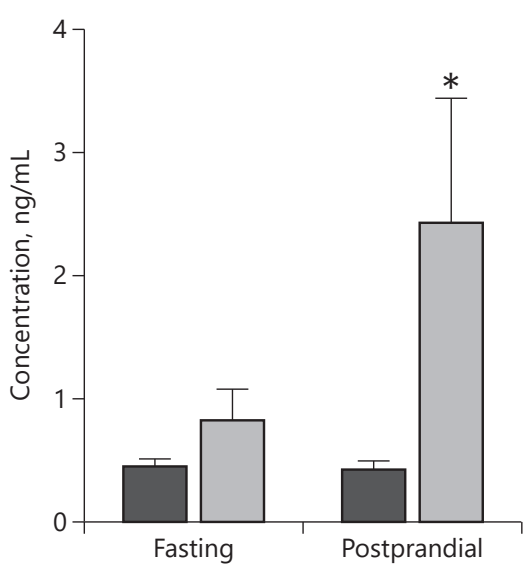

Fig. 6. Influence of food intake on AEA (black bars) and AG (grey bars) plasma concentrations. Depicted are mean values + SD of fasting EC concentrations obtained from 5 healthy subjects (fasting) and the EC concentrations measured from the same subjects $2 \mathrm{~h}$ after a regular lunch (postprandial). AEA, anandamide; AG, arachidonoyl glycerol; EC, endocannabinoid. ${ }^{*} p<0.05$.

from 1.21 to $1.81 \mathrm{ng} / \mathrm{mL}(p=0.014)$ after 2 weeks and slightly decreased thereafter over the next 2 weeks. In contrast, higher AG concentrations in spiked plasma samples appeared not to be susceptible to sample storage as no changes were observed (Fig. 5b). The literature is still controversial concerning the stability of AEA in frozen plasma. The data reported here support other experiments $[30,34,48]$ showing AEA to be fairly stable in frozen plasma, but are in contrast to those of Schreiber et al. [49], showing a significant decrease of AEA concentrations in human plasma within 8 weeks at $-80^{\circ} \mathrm{C}$. Only limited data are available in the literature for $\mathrm{AG}$ assuming sufficient stability in plasma at $-70^{\circ} \mathrm{C}$ for non-spiked samples [30].

\section{Influence of Food Intake}

Figure 6 depicts the influence of recent food intake on plasma concentrations of AEA and AG. No differences were observed for AEA between the fasting and the postprandial status with mean values (SD; RSD) being 0.43 $(0.064 ; 14.6 \%)$ and $0.42(0.073 ; 17.3 \%) \mathrm{ng} / \mathrm{mL}$, respectively. In contrast, AG increased markedly by a factor of 3 after the intake of a full meal. Corresponding mean values (SD; RSD) before and after lunch were $0.82(0.247 ; 30.2 \%)$ and $2.43(1.02 ; 42.1 \%) \mathrm{ng} / \mathrm{mL}$, respectively $(p=0.026)$. A considerably higher interindividual variability was found for AG at both conditions compared to AEA, represented by a high RSD of 30.2 and $42.1 \%$ for the fasting and postprandial state, respectively. The variability even increased after the ingestion of food, underlying the susceptibility of AG to food consumption. These results clearly show the prominent influence of preanalytical conditions on the plasma concentrations of AG and emphasize the need to follow a strict SOP. It is well known that ECs play a key role in the complex regulation of food intake and energy balance [50]. An increase of plasma concentrations of 2-AG after hedonic eating compared to non-hedonic eating in sated subjects has been described [44]. The findings in the present study are in contrast to another study which did not observe any changes in the plasma concentrations of AG measured $1 \mathrm{~h}$ before and $1 \mathrm{~h}$ after food intake [43]. AEA plasma levels were similar $1 \mathrm{~h}$ before and $1 \mathrm{~h}$ after eating a standardized meal but showed a peak immediately before food intake started. These complex time-dependent changes in EC plasma concentrations as well as the influence of energy status and body weight may be responsible for the controversial results found in the literature.

\section{Conclusions}

Since the discovery of the cannabinoid receptors and their endogenous ligands the elucidation of the physiological and pathophysiological role of the ECS and its potential in the treatment of various symptoms in a large number of diseases has attracted the highest research interest. Accordingly, the development of highly sensitive and selective analytical methods to reliably quantitate the low concentrations of the two major ECs, AEA and 2-AG, in plasma and tissue samples was necessary. It was recognized that the determination of ECs is influenced by various difficulties and pitfalls. Limited chemical stability of 2-AG with the $\mathrm{pH}$ - and solvent-dependent acyl migration forming 1-AG equally contributes to the production of analytical artifacts. The biological instability of ECs is, for example, due to the catalytic activity of enzymes present in plasma and the release of AEA from blood cells. Also important are the preanalytical factors, such as the time point of blood collection in relation to the intake of food and the handling and processing of blood samples. These critical analytical and preanalytical issues emphasize the need for careful method development and validation.

In this study we aimed to develop and validate a relatively simple analytical method for the simultaneous quantitation of AEA and AG in human plasma with GC/
16

Med Cannabis Cannabinoids 2018;1:9-18 DOI: $10.1159 / 000489032$
Lanz/Mattsson/Stickel/Dufour/ Brenneisen 
MS as an alternative to the nowadays more common LC/ MS. Particular attention was paid to establish a standardized collection protocol (SOP) which respects preanalytical issues and allows avoiding the formation of artifacts. Liquid-liquid extraction with toluene, which has been reported to result in clean extracts with limited extraction of phospholipids, suppression of acyl migration of 2-AG, and good recovery for ECs, was applied and combined with a simple single-step derivatization by silylation. The validation of sample collection and handling protocols revealed the susceptibility of AG plasma concentrations to food ingestion with a 3 -fold increase $2 \mathrm{~h}$ postprandially and the release of AEA from blood cells even when whole blood was placed on ice for a limited time. Repeated freezing and thawing of plasma samples should be avoided as well as prolonged storage of samples due to a limited stability even at $-80^{\circ} \mathrm{C}$. These findings show that a preanalytical SOP is essential and results from retrospective analyses of AEA in blood samples collected under unknown conditions are misleading and scientifically not sound. Therefore, it appears also unlikely that AEA and 2-AG can be used as biomarkers in a clinical environment with less strictly controlled preanalytical parameters. The validation of the analytical method showed that $\mathrm{EC}$ analysis is feasible even with a single-quadrupole GC/
MS instrument, which is available in many research and service laboratories. Good extraction recovery by using toluene, excellent stability of extracts derivatized by silylation, and good assay performance regarding specificity, accuracy, precision, linearity, and sensitivity were found.

In summary, we report here a simple, precise, and robust GC/MS method for the simultaneous quantitation of AEA and 2-AG in human plasma. However, limited preanalytical chemical and biological stability of the studied ECs have to be taken into account.

\section{Acknowledgments}

The authors thank Jeannine Joneli from the laboratory of Clinical Pharmacology of the Institute of Infectious Diseases, University of Bern, and the nurses from the Hepatology Outpatient Clinic of the University Hospital Bern for the sample collection. Philip Sachse and Vreni Schneider are acknowledged for their valuable contributions in the sample processing and management and Dr. Nasser Semmo for fruitful discussions.

\section{Disclosure Statement}

The authors have declared no conflict of interest.

\section{References}

1 Hanus LO: Pharmacological and therapeutic secrets of plant and brain (endo)cannabinoids. Med Res Rev 2009;29:213-271.

2 Howlett AC: Inhibition of neuroblastoma adenylate cyclase by cannabinoid and nantradol compounds. Life Sci 1984;35:1803-1810.

3 Howlett AC, Fleming RM: Cannabinoid inhibition of adenylate cyclase. Pharmacology of the response in neuroblastoma cell membranes. Mol Pharmacol 1984;26:532-538.

4 Devane WA, Dysarz FA 3rd, Johnson MR, Melvin LS, Howlett AC: Determination and characterization of a cannabinoid receptor in rat brain. Mol Pharmacol 1988;34:605613.

5 Gerard CM, Mollereau C, Vassart G, Parmentier M: Nucleotide sequence of a human cannabinoid receptor cDNA. Nucleic Acids Res 1990;18:7142.

6 Gerard CM, Mollereau C, Vassart G, Parmentier M: Molecular cloning of a human cannabinoid receptor which is also expressed in testis. Biochem J 1991;279(pt 1):129-134.

7 Matsuda LA, Lolait SJ, Brownstein MJ, Young AC, Bonner TI: Structure of a cannabinoid receptor and functional expression of the cloned cDNA. Nature 1990;346:561-564.
8 Munro S, Thomas KL, Abu-Shaar M: Molecular characterization of a peripheral receptor for cannabinoids. Nature 1993;365:61-65.

9 Griffin G, Tao Q, Abood ME: Cloning and pharmacological characterization of the rat $\mathrm{CB}_{2}$ cannabinoid receptor. J Pharmacol Exp Ther 2000;292:886-894.

10 Shire D, Calandra B, Rinaldi-Carmona M, Oustric D, Pessegue B, Bonnin-Cabanne O, Le Fur G, Caput D, Ferrara P: Molecular cloning, expression and function of the murine CB2 peripheral cannabinoid receptor. Biochim Biophys Acta 1996;1307:132-136.

11 Gong JP, Onaivi ES, Ishiguro H, Liu QR, Tagliaferro PA, Brusco A, Uhl GR: Cannabinoid CB2 receptors: immunohistochemical localization in rat brain. Brain Res 2006;1071:10-23.

12 Howlett AC, Barth F, Bonner TI, Cabral G, Casellas P, Devane WA, Felder CC, Herkenham M, Mackie K, Martin BR, Mechoulam R, Pertwee RG: International Union of Pharmacology. XXVII. Classification of cannabinoid receptors. Pharmacol Rev 2002;54:161-202.

13 Onaivi ES, Ishiguro H, Gong JP, Patel S, Perchuk A, Meozzi PA, Myers L, Mora Z, Tagliaferro P, Gardner E, Brusco A, Akinshola BE, Liu QR, Hope B, Iwasaki S, Arinami T,
Teasenfitz L, Uhl GR: Discovery of the presence and functional expression of cannabinoid CB2 receptors in brain. Ann NY Acad Sci 2006; 1074:514-536.

14 Devane WA, Hanus L, Breuer A, Pertwee RG, Stevenson LA, Griffin G, Gibson D, Mandelbaum A, Etinger A, Mechoulam R: Isolation and structure of a brain constituent that binds to the cannabinoid receptor. Science 1992; 258:1946-1949.

15 Sugiura T, Kondo S, Sukagawa A, Nakane S, Shinoda A, Itoh K, Yamashita A, Waku K: 2-Arachidonoylglycerol: a possible endogenous cannabinoid receptor ligand in brain. Biochem Biophys Res Commun 1995;215:89-97.

16 Mechoulam R, Ben-Shabat S, Hanus L, Ligumsky M, Kaminski NE, Schatz AR, Gopher A, Almog S, Martin BR, Compton DR: Identification of an endogenous 2-monoglyceride, present in canine gut, that binds to cannabinoid receptors. Biochem Pharmacol 1995;50:83-90.

17 Luchicchi A, Pistis M: Anandamide and 2-arachidonoylglycerol: pharmacological properties, functional features, and emerging specificities of the two major endocannabinoids. Mol Neurobiol 2012;46:374-392.
Endocannabinoids and GC/MS:

Challenges and Pitfalls
Med Cannabis Cannabinoids 2018;1:9-18 DOI: $10.1159 / 000489032$ 
18 Hanus LO: Discovery and isolation of anandamide and other endocannabinoids. Chem Biodivers 2007;4:1828-1841.

19 Di Marzo V, De Petrocellis L: Why do cannabinoid receptors have more than one endogenous ligand? Philos Trans R Soc Lond B Biol Sci 2012;367:3216-3228.

20 Atakan Z: Cannabis, a complex plant: different compounds and different effects on individuals. Ther Adv Psychopharmacol 2012;2: 241-254.

21 Pacher P, Kunos G: Modulating the endocannabinoid system in human health and disease - successes and failures. FEBS J 2013;280: 1918-1943.

22 Russo EB: Clinical endocannabinoid deficiency reconsidered: current research supports the theory in migraine, fibromyalgia, irritable bowel, and other treatment-resistant syndromes. Cannabis Cannabinoid Res 2016; 154-165.

23 Zoerner AA, Gutzki FM, Batkai S, May M, Rakers C, Engeli S, Jordan J, Tsikas D: Quantification of endocannabinoids in biological systems by chromatography and mass spectrometry: a comprehensive review from an analytical and biological perspective. Biochim Biophys Acta 2011;1811:706-723.

24 Balvers MG, Verhoeckx KC, Witkamp RF: Development and validation of a quantitative method for the determination of 12 endocannabinoids and related compounds in human plasma using liquid chromatography-tandem mass spectrometry. J Chromatogr B Analyt Technol Biomed Life Sci 2009;877:15831590.

25 Fanelli F, Di Lallo VD, Belluomo I, De Iasio R, Baccini M, Casadio E, Gasparini DI, Colavita M, Gambineri A, Grossi G, Vicennati V, Pasquali R, Pagotto U: Estimation of reference intervals of five endocannabinoids and endocannabinoid related compounds in human plasma by two dimensional-LC/MS/MS. J Lipid Res 2012;53:481-493.

26 Lam PM, Marczylo TH, El-Talatini M, Finney M, Nallendran V, Taylor AH, Konje JC: Ultra performance liquid chromatography tandem mass spectrometry method for the measurement of anandamide in human plasma. Anal Biochem 2008;380:195-201.

27 Marczylo TH, Lam PM, Nallendran V, Taylor AH, Konje JC: A solid-phase method for the extraction and measurement of anandamide from multiple human biomatrices. Anal Biochem 2009;384:106-113.

28 Sergi M, Battista N, Montesano C, Curini R, Maccarrone M, Compagnone D: Determination of the two major endocannabinoids in human plasma by $\mu$-SPE followed by HPLCMS/MS. Anal Bioanal Chem 2013;405:785793.

29 Thomas A, Hopfgartner G, Giroud C, Staub C: Quantitative and qualitative profiling of endocannabinoids in human plasma using a triple quadrupole linear ion trap mass spectrometer with liquid chromatography. Rapid Commun Mass Spectrom 2009;23:629-638.
30 Zoerner AA, Batkai S, Suchy MT, Gutzki FM, Engeli S, Jordan J, Tsikas D: Simultaneous UPLC-MS/MS quantification of the endocannabinoids 2-arachidonoyl glycerol (2AG), 1-arachidonoyl glycerol (1AG), and anandamide in human plasma: minimization of matrix-effects, 2AG/1AG isomerization and degradation by toluene solvent extraction. J Chromatogr B Analyt Technol Biomed Life Sci 2012;883-884:161-171.

31 Kasai HF, Tsubuki M, Takahashi K, Honda T, Ueda H: Analyses of anandamide and endocannabinoid-like compounds using collisioninduced dissociation in fast atom bombardment ionization-mass spectrometry and gas chromatography/chemical ionization-mass spectrometry. Anal Sci 2003;19:1593-1598.

32 Muccioli GG, Stella N: An optimized GC-MS method detects nanomolar amounts of anandamide in mouse brain. Anal Biochem 2008; 373:220-228.

33 Obata T, Sakurai Y, Kase Y, Tanifuji Y, Horiguchi T: Simultaneous determination of endocannabinoids (arachidonylethanolamide and 2-arachidonylglycerol) and isoprostane (8-epiprostaglandin F2a) by gas chromatography-mass spectrometry-selected ion monitoring for medical samples. J Chromatogr B Analyt Technol Biomed Life Sci 2003;792: 131-140.

34 Zoerner AA, Gutzki FM, Suchy MT, Beckmann B, Engeli S, Jordan J, Tsikas D: Targeted stable-isotope dilution GC-MS/MS analysis of the endocannabinoid anandamide and other fatty acid ethanol amides in human plasma. J Chromatogr B Analyt Technol Biomed Life Sci 2009;877:2909-2923.

35 Hardison S, Weintraub ST, Giuffrida A: Quantification of endocannabinoids in rat biological samples by GC/MS: technical and theoretical considerations. Prostaglandins Other Lipid Mediat 2006;81:106-112.

36 Skonberg C, Artmann A, Cornett C, Hansen $\mathrm{SH}$, Hansen HS: Pitfalls in the sample preparation and analysis of $\mathrm{N}$-acylethanolamines. J Lipid Res 2010;51:3062-3073.

37 Higuchi S, Irie K, Nakano T, Sakamoto Y, Akitake Y, Araki M, Ohji M, Furuta R, Katsuki M, Yamaguchi R, Matsuyama K, Mishima K, Iwasaki K, Fujiwara M: Reducing acyl migration during purification of 2-arachidonoylglycerol from biological samples before gas chromatography mass spectrometry analysis. Anal Sci 2010;26:1199-1202.

38 Wood JT, Williams JS, Pandarinathan L, Courville A, Keplinger MR, Janero DR, Vouros P, Makriyannis A, Lammi-Keefe CJ: Comprehensive profiling of the human circulating endocannabinoid metabolome: clinical sampling and sample storage parameters. Clin Chem Lab Med 2008;46:1289-1295.
39 El-Talatini MR, Taylor AH, Konje JC: The relationship between plasma levels of the endocannabinoid, anandamide, sex steroids, and gonadotrophins during the menstrual cycle. Fertil Steril 2010;93:1989-1996.

40 Feuerecker M, Hauer D, Gresset T, Lassas S, Kaufmann I, Vogeser M, Briegel J, Hornuss C, Chouker A, Schelling G: Effect of an acute consumption of a moderate amount of ethanol on plasma endocannabinoid levels in humans. Alcohol Alcohol 2012;47:226-232.

41 Heyman E, Gamelin FX, Goekint M, Piscitelli F, Roelands B, Leclair E, Di Marzo V, Meeusen $R$ : Intense exercise increases circulating endocannabinoid and BDNF levels in humans possible implications for reward and depression. Psychoneuroendocrinology 2012;37: 844-851.

42 Jumpertz R, Guijarro A, Pratley RE, Piomelli D, Krakoff J: Central and peripheral endocannabinoids and cognate acylethanolamides in humans: association with race, adiposity, and energy expenditure. J Clin Endocrinol Metab 2011;96:787-791.

43 Gatta-Cherifi B, Matias I, Vallee M, Tabarin A, Marsicano G, Piazza PV, Cota D: Simultaneous postprandial deregulation of the orexigenic endocannabinoid anandamide and the anorexigenic peptide YY in obesity. Int J Obes (Lond) 2012;36:880-885.

44 Monteleone P, Piscitelli F, Scognamiglio P, Monteleone AM, Canestrelli B, Di Marzo V, Maj M: Hedonic eating is associated with increased peripheral levels of ghrelin and the endocannabinoid 2-arachidonoyl-glycerol in healthy humans: a pilot study. J Clin Endocrinol Metab 2012;97:E917-E924.

45 Sipe JC, Scott TM, Murray S, Harismendy O, Simon GM, Cravatt BF, Waalen J: Biomarkers of endocannabinoid system activation in severe obesity. PLoS One 2010;5:e8792.

46 Peters FT, Drummer OH, Musshoff F: Validation of new methods. Forensic Sci Int 2007; 165:216-224.

47 Vogeser M, Hauer D, Christina Azad S, Huber E, Storr M, Schelling G: Release of anandamide from blood cells. Clin Chem Lab Med 2006;44:488-491.

48 Palandra J, Prusakiewicz J, Ozer JS, Zhang Y, Heath TG: Endogenous ethanolamide analysis in human plasma using HPLC tandem MS with electrospray ionization. J Chromatogr $\mathrm{B}$ Analyt Technol Biomed Life Sci 2009;877: 2052-2060.

49 Schreiber D, Harlfinger S, Nolden BM, Gerth CW, Jaehde U, Schomig E, Klosterkotter J, Giuffrida A, Astarita G, Piomelli D, Markus Leweke F: Determination of anandamide and other fatty acyl ethanolamides in human serum by electrospray tandem mass spectrometry. Anal Biochem 2007;361:162-168.

50 Di Marzo V, Ligresti A, Cristino L: The endocannabinoid system as a link between homoeostatic and hedonic pathways involved in energy balance regulation. Int J Obes (Lond) 2009;33(suppl 2):S18-S24. 